\title{
РЕЦЕНЗІї
}

DOI: 10.34015/2523-4552.2020.2.14

УДК 351. 74:338. 2(-91) «1931/1941»
Кириченко В. $\boldsymbol{\epsilon}_{\text {., }}$

доктор юридичних наук, професор, професор кафедри фундаментальних та юридичних дисциплін Харківського національного університету внутрішніх справ

\section{ІСТОРИКО-ПРАВОВЕ ДОСЛІДЖЕННЯ МІЛІЦІЇ УКРАЇНИ ПЕРЕДВОЄННОГО ДЕСЯТИЛІТТЯ (1931-1941 РОКИ)}

Рец. на кн.: Бандурка О. М., Греченко В. А. Міліція в Україні в період посилення тоталітарного режиму (1931-1941 рр.): історико-правове дослідження: [монографія]. Харків : Золота миля; Панов, 2020. 444 с.

Останнім часом в українському суспільстві зростає занепокоєння станом охорони правопорядку в державі, здатністю правоохоронних органів протидіяти розгулу екстремізму (як правого, так і будь-якого), ефективно боротися зі злочинністю, гарантувати безпеку громадян. I це цілком природно, адже особиста безпека, захист життя, здоров'я, людської гідності, власних осель та майна від злочинних посягань турбують людей. Утім криміногенна ситуація лише погіршується, якісна боротьба зі злочинністю не ведеться, корумпованість зростає, все це породжує у суспільства потребу вимагати від держави гарантій всеосяжної безпеки.

У свою чергу незадоволеність наслідками реформаторської діяльності тісно пов'язана 3 суб'єктивними поглядами людей щодо правопорядку. Однією з причин реформування органів внутрішніх справ, й зокрема міліції, рефор- матори називали те, що існуюча інституція отримана Україною у спадок від Радянського Союзу та її неефективність $\epsilon$ наслідком невідповідності сучасним соціальним, економічним та політичним реаліям. Проте спроба відринути й забути, почати з нового листа, не завжди є виправданою. Досвід минулого корисний сучасникам своїми висновками як позитивними, так і негативними. Без нього неможливе переосмислення існуючих як в науці, так і в правоохоронній практиці догм, міфів та стереотипів, а також пошук нових, дієвих у сучасних умовах, форм та методів забезпечення правопорядку, розкритті загальних закономірностей удосконалення різних ланок державного механізму. Власне цим обумовлена нагальна потреба в історикоправовому дослідженні стану та генези органів внутрішніх справ їх діяльності щодо забезпечення порядку i безпеки без яких будь-яке суспільство приречене на загибель. 
На задоволення цієї суспільної потреби й спрямоване нове історикоправове дослідження знаних й авторитетних фахівців у цій царині, науковців Харківського національного університету внутрішніх справ О. М. Бандурки та В. А. Греченка, яке щойно вийшло друком у харківському виданні «Золота миля» під назвою: «Міліція в Україні в період посилення тоталітарного режиму (1931-1941 рр.)». Це вже третя монографія з багатотомної серії досліджень присвячених історії поліції та міліції ${ }^{1}$, яку з нетерпінням очікували як фахівці, так і ті, кого цікавить та непокоїть ця тематика.

У своїх наукових розвідках автори дісталися того періоду вітчизняної історії, коли більшовики після захоплення влади в Україні стали до створення нової ланки державного апарату - робітничо-селянської міліції. Відтоді розпочинається тривалий шлях пошуку оптимальних форм організації міліції, унормування іiї діяльності, створення кадрового апарату та визначення його правового статусу, повноважень і компетенцій, тощо. I одним з найважливіших етапів в історії радянських правоохоронних органів $\epsilon$ передвоєнне десятиліття - десятиліття реформ та численних перебудов. Невипадково дослідники звертають увагу на сучасний стан речей в Україні й ті елементи в системі держави, які забезпечують їі життєдіяльність. Саме міліція була одним 3 тих системотворних елементів держави, який забезпечував життєдіяльність суспільства.

Історія розвитку органів внутрішніх справ передвоєнного періоду складна й суперечлива і тут доречно вести мову про певну тенденційність при їі висвітленні в історіографії. До того ж сучасні дослідники зосереджуються, переважно, на питаннях загального характеру і вкрай мало приділяли уваги державним структурам, що забезпечують безпеку суспільства. Такий стан дослідження проблеми змусив авторів вдатися до критичного системного підходу щодо оцінки відомих фактів й документів та спрямувати свої зусилля на залучення й дослідження невідомих широкому загалу джерел.

Автори комплексно підійшли до обрання об'єкту та предмету дослідження розглядаючи правовідносини пов'язані з організаційним устроєм та функціонуванням міліції в Україні у 1930-і роки. Відповідно до цього класичною, у своїй будові, $\epsilon$ й структура монографії, яка складається 3 трьох розділів присвячених: стану наукової розробки проблеми; організаційним аспектам; та діяльності міліції в означений період.

Зокрема у першому розділі монографії читач знайде грунтовний аналіз нечисленної історіографії як радянського періоду, так і доби незалежності. Варто відзначити, що історіографічні студії проводились з врахуванням тої методологічної динаміки та парадигмальної концептуалізації, яка була притаманна відповід-

1 Бандурка О. М., Греченко В. А., Ярмиш О. Н. Поліція в Україні: історико-правове дослідження (початок XVIII - 1917 р.) [монографія]. Харків : Золота миля, 2012. 616 с.; Бандурка О. М., Греченко В. А., Ярмиш О. Н. Становлення та розвиток міліції України (1921-1930 роки): історико-правове дослідження [монографія]. Харків : Золота миля, 2015. 498 с. 
ним історичним періодам. Не менше привертає до себе увагу й підрозділ присвячений джерельній базі, в якому після відповідної класифікації представлений огляд трьох основних груп джерел. При роботі над монографією використана чисельна загальна та спеціальна література, нормативні акти та матеріали партійних, радянських органів, а також громадських організацій. Особливий інтерес викликає залучення до наукового обігу джерел архівного походження із запровадженням відповідної систематизації та класифікації. Власне порівняльний аналіз відомих джерел $з$ нововведеними дозволив відтворити цілісну картину діяльності міліції республіки, показати особливості формування їі структури, подальшу трансформацію та основні напрями діяльності. Також серед неопублікованих джерел привертають до себе підвищену увагу рапорти міліціонерів, слідчих, листи очільників міліції, дисциплінарні провадження та кримінальні справи щодо працівників міліції. Й нарешті в підрозділі щодо методології дослідження автори висвітлюють свій методологічний інструментарій в основу якого було покладено загальнонауковий принцип історизму, органічно доповнений багатофакторністю та міждисциплінарністю. Звичайно, що для досягнення мети дослідниками було використано широкий спектр як загальнонаукових, так і спеціальних методів наукового пізнання.

Оригінальною є обрана дослідниками структурна будова другого розділу монографії, присвяченого організації міліції. Подавши правові засади діяльності міліції та еволюцію iï організаційних форм протягом 1931-1934 pр., автори простежують подальшу реорганізацію структури цієї інституції та зміни в ії управлінні, що тривали впритул до початку Другої світової війни. Подальше дослідження організаційних засад стосується вже періоду, коли Західну Україну було приєднано до Української республіки у складі СРСР. Органічно, в цьому контексті, виглядає підрозділ присвячений підготовці кадрів для органів внутрішніх справ. Не меншу зацікавленість викликає й останній підрозділ, що висвітлює правове, соціальне й, головне, матеріальне становище працівників міліціï.

Щодо останнього розділу дослідження, то він присвячений основним аспектам діяльності міліції у передвоєнне десятиліття. Перші три підрозділи висвітлюють боротьбу 3 різними видами кримінальних злочинів починаючи від найбільш суспільно небезпечних, як от протидія бандитизму, боротьба з економічними злочинними діяннями та завершуючи іншими видами передбаченими кримінальним кодексом. Окремий розділ приділено гострій темі - міліція та репресії 19371939 рр., в якому показано як маховик репресій пройшовся по самому Народному комісаріату внутрішніх справ, до того ж неодноразово. Й завершено розділ аналізом адміністративної діяльності міліції.

Грунтовні підсумки дослідження авторами підбито окремо у висновках, що також додає вагомості цій історико-правовій розвідці, залишаючи по собі приємні враження. Раніше було зауважено, що обраний предмет дослідження $\epsilon$ суперечливим та багатоаспектним, щонайменше про це свідчить той аналіз історіографії теми, який провели дослід- 
ники. Звісно сьогоденна гіперполітизація суспільства, від якої не убереглася й українська історична та історико-правова наука, не дасть можливості уникнути суб'єктивного підходу до оцінки дослідження. Проте, можна без перебільшення стверджувати, що рецензована монографія сприяє створенню об'єктивної кар- тини історії міліції в Україні в період посилення тоталітарного режиму в Радянському Союзі. Сподіваємось, що іiї результати будуть використані для подальшого вдосконалення теорії та практики державного будівництва, розробки нормативно-правової бази для органів MBC в сучасних умовах. 